\title{
Development of Lightweight Radiators for Lunar Based Power Systems
}

Albert J. Juhasz and Harvey S. Bloomfield

Lewis Research Center

Cleveland, Ohio

Prepared for the

5th European Symposium on Space and Environmental Control Systems and the 24th International Conference on Environmental Systems cosponsored by ESA, SAE, ASME, AIChE, and AIAA Friedrichshafen, Federal Republic of Germany, June 20-23, 1994

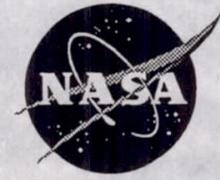

National Aeronautics and Space Administration

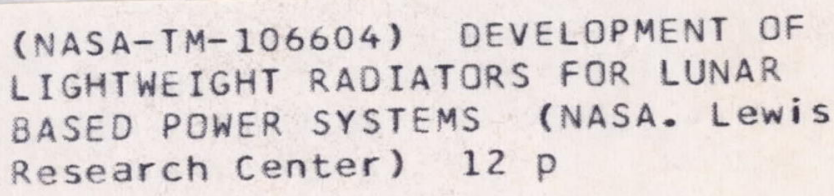




\title{
DEVELOPMENT OF LIGHTWEIGHT RADIATORS FOR LUNAR BASED POWER SYSTEMS
}

\author{
Albert J. Juhasz and Harvey S. Bloomfield \\ National Aeronautics and Space Administration \\ Lewis Research Center \\ Cleveland, Ohio 44135
}

\begin{abstract}
This report discusses application of a new lightweight carbon-carbon (C-C) space radiator technology developed under the NASA Civil Space Technology Initiative (CSTI) High Capacity Power Program to a $20 \mathrm{~kW}_{\mathrm{e}}$ lunar based power system. This system comprises a nuclear (SP-100 derivative) heat source, a Closed Brayton Cycle (CBC) power conversion unit with heat rejection by means of a plane radiator. The new radiator concept is based on a C-C composite heat pipe with integrally woven fins and a thin walled metallic liner for containment of the working fluid. Using measured areal specific mass values $\left(1.5 \mathrm{~kg} / \mathrm{m}^{2}\right)$ for flat plate radiators, comparative $\mathrm{CBC}$ power system mass and performance calculations show significant advantages if conventional heat pipes for space radiators are replaced by the new C-C heat pipe technology.
\end{abstract}

\section{INTRODUCTION}

Ever since the first lunar landing almost 25 years ago, establishment of a permanent lunar presence by humans has been an intriguing concept. Establishment of lunar outposts, bases or even lunar colonies has been the topic of numerous studies as exemplified in references 1 to 4 . Lunar bases would represent strategic assets for development and testing of space technologies required for further exploration of the solar system. Technologies culminating in utilization of lunar resources would enable even more ambitious projects, such as construction of optical and radio astronomy facilities. Besides the tremendous benefits resulting from the absence of radio interference on the lunar far side, operation of a lunar radio telescope as an element of a "Very Large Baseline Array" (VLBA) which includes earth based telescopes a separation distance some thirty times wider than the maximum possible separation on earth would be possible. Since telescope resolving power is determined by the ratio of wavelength to baseline separation distance, resolutions could then approach values of less than $10^{-5}$ arc seconds at centimeter scale wavelengths, permitting detailed observations on disks of nearby solar size stars [5].
A key prerequisite for the establishment of a lunar outpost is a reliable power system to supply the energy requirements for science, life support, and operational activities. Since such a power system should provide continuous output throughout the 29.5 day synodic month, half of which (354 hours) receives no sunlight, the advantage of a sun independent heat source is obvious. Several studies have been performed on using the lunar soil (regolith) as a thermal energy storage material in conjunction with a solar power system. A conclusion reached [3] was that while thermal energy could be stored as relatively low temperature sensible heat, high temperature latent heat storage required for a viable solar dynamic power system would require an elaborate heat distribution and retrieval system, technologically so complex, that the concept was judged to be impractical.

To overcome the problems associated with the energy storage requirements associated with solar power systems for lunar applications power plants with nuclear heat sources offer definite advantages. With the energy source being truly independent of insolation, no energy storage would be required and the overall system mass requirement would be far lower. Moreover, the reactor shielding problem would be greatly simplified by taking effective advantage of the local crater topography and the use of indigenous lunar regolith materials. An application of the nuclear reactor technology being developed under the SP-100 program was proposed [4], utilizing a "Free Piston Stirling" power conversion system with linear alternator produced power output. This concept was based on the $2.5 \mathrm{MW}_{\mathrm{t}}$ fast spectrum lithium cooled reactor supplying heat at $1300 \mathrm{~K}$ to 8 modular Stirling engines. Maximum power output was rated at $825 \mathrm{~kW}_{\mathrm{e}}$. For this concept the reactor was located in a $4 \mathrm{~m}$ deep cylindrical excavation, requiring less than $40 \mathrm{~m}^{3}$ of lunar soil to be removed. The power system proposed here also uses a nuclear heat source. But since the nominal output power level is only $20 \mathrm{~kW}_{\mathrm{e}}$ the reactor thermal power requirement is lower by more than an order of magnitude. Consequently the shielding requirements are even lower than those for the system cited above. The power conversion system is based on the Closed Cycle Gas Turbine (CCGT), also referred to as the CBC, that had been developed [6] for the initial configuration of the space station "Freedom" and also proposed for a demonstration of scaled 
down SP-100 reactor coupled to a CBC [7] to meet the power requirements of an interplanetary electric propulsion mission. The power system benefits resulting from the use of a lightweight C-C radiator in the lunar day/night temperature environment will be explored in the succeeding sections.

\section{LIGHTWEIGHT C-C RADIATOR DEVELOPMENT}

Development of this technology was conducted under an "Advanced Radiator Concepts" (ARC) contract between the NASA Lewis Research Center and Rockwell International Co. as a major effort of the Civil Space Technology (CSTI) Thermal management program [8]. As indicated in figure 1 (a), the basic element of a C-C radiator is a carbon-carbon heat pipe consisting of a tubular $\mathrm{C}-\mathrm{C}$ pressure shell with integrally woven fins and a thin walled $(0.064 \mathrm{~mm})$ metallic liner of niobium-zirconium alloy which has been furnace brazed to the inner surface of the composite shell for containment of the heat pipe working fluid. A short extension of this liner protruding beyond one end of the shell forms the evaporator section which is in thermal contact with the power system radiator working fluid. The wall thickness for the evaporator and the two end caps is about $0.4 \mathrm{~mm}$, permitting a structurally rigid radiator panel assembly. The surface emissivity of the C-C shell and fins was 0.85 . Further details on the fabrication and assembly of the heat pipe, using the originally available T-300 C-C composite for the finned shell have been reported previously $[9,10]$. A $35 \mathrm{~cm}$ long heat pipe with $2.5 \mathrm{~cm}$ wide fins was successfully tested [11], starting from room temperature with the potassium working fluid in the frozen state to temperatures near $700 \mathrm{~K}$. Figure 1 (b) shows a sketch of the instrumented test article.

Since the axial thermal conductivity of the heat pipe tested was limited to a maximum of $80 \mathrm{~W} / \mathrm{m}-\mathrm{K}$, an additional task was added to the contract, to study methods of fabricating the woven preform finned shells using higher conductivity fiber yarn which is more difficult to weave. Several lengths of P-95 WG composite shells were successfully fabricated under this task. Since the conductivity of this composite was about $300 \mathrm{~W} / \mathrm{m}-\mathrm{K}$ at the targeted operating temperature of $800 \mathrm{~K}$ (equivalent to the SP-100 thermoelectric power system heat rejection temperature), the fin length (root-to-tip dimension) was increased from 2.5 to $5 \mathrm{~cm}$, without any loss in fin efficiency. A comparison of the two fin designs and a detailed heat pipe component weight breakdown is given in Table 1, which shows that the long finned P-95 WG heat pipe achieves a 69 percent increase in radiating area at a mere 15 percent increase in mass. As a result the areal specific mass decreases from 2.1 to $1.45 \mathrm{~kg} / \mathrm{m}^{2}$. The heat rejection capacity as function of temperature for the two C-C composites, figure 2, shows that the higher conductivity P95 WG composite heat pipe is capable of rejecting over 50 percent more heat than the T-300 composite, due to the higher radiating area.

\section{LUNAR ENVIRONMENT}

The lunar environmental sink temperatures over the synodic month period from full moon to the next full moon are shown in figure 3 (a). Using the Stefan-Boltzmann law, these equilibrium temperatures can be computed from a balance of direct solar heat absorbed and low temperature infra-red heat emitted, given surface emissivity $(\varepsilon)$ and absorptivity $(\alpha)$ values. The relationship is given in equation 1 as:

$$
\mathrm{T}_{\mathrm{e}}=\left((\alpha / \varepsilon) \times\left(\mathrm{L} / 4 \pi \sigma \mathrm{d}^{2}\right)\right)^{.25}
$$

where

$T_{e}$ is the equilibrium surface temperature in $\mathrm{K}$

$\mathrm{L}=3.9 \times 10^{26} \mathrm{~W}$ is the solar luminosity

$\sigma=5.67 \times 10^{-8} \mathrm{~W} / \mathrm{m}^{2} \mathrm{~K}^{4}$ is the Stefan-Boltzmann constant

$\mathrm{d}=1.496 \times 10^{11} \mathrm{~m}$, the average sun-to-lunar orbit distance

To calculate the equilibrium surface temperatures from lunar noon to midnight, the $(\alpha / \varepsilon)$ ratio was varied from 0.93 to .003 , assuming the power system site to be located near the lunar equator. Radiatively coupling the lunar sky temperatures with the temperature profile shown, a mean effective daytime sink temperature of $360 \mathrm{~K}$ and an effective night-time temperature of $90 \mathrm{~K}$ was arrived at for power system heat rejection calculations. An interesting result was arrived at if the $\alpha / \varepsilon$ ratio was allowed to drop to 0.1 , a condition which could be easily obtained by locating a vertical radiator centrally in an area that is covered by a highly reflective aluminized blanket. Since this blanket cover would be very thin (near $0.05 \mathrm{~mm}$ ), its mass would be less than $0.1 \mathrm{~kg} / \mathrm{m}^{2}$. Figure 3(b) shows that for a radiator height of 1 meter a cover width of about 6 meters on each side would be sufficient to lower the daytime effective sink temperature to about $230 \mathrm{~K}$. Also shown in figure $3(\mathrm{~b})$ that the equivalent sink temperature for a horizontal radiator would be near $340 \mathrm{~K}$ for the lunar noon insolation. Figure 3 (c) shows a simple implementation of a power system with a . radiator utilizing an aluminized reflective cover.

These results have significant effects on lunar power cycle calculations as discussed in the next paragraphs. 


\section{CLOSED CYCLE GAS TURBINE (CCGT) POWER SYSTEM}

Coupling of a reactor heat source to a CCGT, also referred to as a "Closed Brayton Cycle" (CBC), has been studied in the mid sixties $[12,13]$, especially for high power levels for terrestrial power plants utilizing high temperature gas reactors. The present study utilized an updated version of the CBC system described in [7] as shown in figure 4. The main change was to raise the turbine inlet temperature to $1350 \mathrm{~K}$ by inserting a 90 percent effectiveness $\mathrm{Li}-\mathrm{He} / \mathrm{Xe}$ heat exchanger between the reactor and the power system loop. Also, besides replacing the aluminum honeycomb pumped loop radiator by the C-C composite heat pipe design, the heat rejection subsystem was simplified by allowing direct heat transfer between the $\mathrm{CBC}$ working fluid and the heat pipe evaporators, rather than use an intermediate gas-liquid heat exchanger. The CBC working fluid was the same $\mathrm{He} / \mathrm{Xe}$ mixture with a molecular weight of 83.8. The radial compressor and turbine diameters were kept at $0.106 \mathrm{~m}$ and $.15 \mathrm{~m}$, respectively, and the design speed was maintained at $36000 \mathrm{rpm}$. Compressor and turbine efficiencies were computed for the proper pressure ratios on the basis of 0.85 infinitesimal stage efficiency. The alternator, located on the same shaft, designed to generate current at 1.2 $\mathrm{khz}$, accomplishes nearly an order of magnitude mass reduction, compared to a generator producing $60 \mathrm{hz}$. A detailed component mass breakdown for the reference system is shown in table 2.

POWER SYSTEM DESIGN STUDIES - Using an existing $\mathrm{CBC}$ power system mass optimization code developed by the author, performance and system mass computations were carried out under four sets of input conditions as indicated in columns 1 to 4 of table 3 . The information contained in these columns permits performance and overall system mass comparisons between a system operating during the lunar day, utilizing a traditional flat plate radiator having a specific mass of $5 \mathrm{~kg} / \mathrm{m}^{2}$, to a system using the C-C composite radiator (specific mass of $1.5 \mathrm{~kg} / \mathrm{m}^{2}$ ) operating in the following lunar environments: daytime (column 2), night-time (column 3), and daytime with a reflective aluminized mylar blanket covering an area adjacent to the radiator, as discussed above. The mass optimizations resulted in four different power system designs as can be observed from the system parameters shown in the four columns. For simplicity, the highlighted key parameters of: cycle temperature ratio, thermal efficiency, sink temperature, radiator area, and system mass, give an essential description of these systems. Due to its heavier radiator material the system in column (1) is limited to a temperature ratio of 2.9 , yielding an efficiency of $27 \%$, a radiator area of about $23 \mathrm{~m}^{2}$, and an overall system mass of $1460 \mathrm{~kg}$. Although not shown in the table, a doubling of radiator specific mass to $10 \mathrm{~kg} / \mathrm{m}^{2}$ would have lowered the efficiency to $23 \%$ and raised the system mass to $1600 \mathrm{~kg}$.

Column (2) shows that with the lighter C-C radiator the temperature ratio could be increased to 3.2 , resulting in a thermal efficiency over $32 \%$, a radiator area of $30 \mathrm{~m}^{2}$, and an overall system mass of only $1351 \mathrm{~kg}$. Lunar night operation and use of a reflective cover (columns $3 \& 4$ ) results in efficiencies of over $43.3 \%$ and $40.6 \%$, respectively. Note that the overall system masses for the two conditions differ by less than $10 \mathrm{~kg}$. Even after allowing for the additional mass of the blanket (about $10 \mathrm{~kg}$ for $120 \mathrm{~m}^{2}$ ), the strategic value of this device is obvious. Of course, special care will have to be taken to prevent lunar dust from covering the blanket.

Having obtained the mass variations for systems designed specifically for the extremes in environmental conditions, we next investigated the performance of a single compromise system, table 4 , at the same conditions, except for including a traditional radiator (column 1) for comparison. With a constant temperature ratio of 3.4, thermal efficiency is fixed near $35 \%$, with minor deviations due small variations in pressure ratio. Note the $175 \mathrm{~kg}$ mass savings resulting from replacement of the traditional with a C-C radiator of approximately $40 \mathrm{~m}^{2}$ for the lunar midday condition. Also note that the CBC operating during the lunar night requires only about half the radiator area to produce the same power. Similarly, use of a reflective blanket reduces the radiator area requirement from 40 to $23 \mathrm{~m}^{2}$ during daytime operation. The significance of these results is twofold:

(1) If a reflective blanket can be deployed around a lunar power system radiator the radiating area requirement for daytime operation can be reduced by $43 \%$.

(2) For lunar power systems designed to deliver rated output power during the lunar day without reliance on a reflective cover, the excess radiator area available during night time operation can be utilized to produce excess power for storage. This would also require reactor thermal power modulation, working fluid inventory control and alternator field adjustment.

\section{EXTENSION OF RESULTS TO HIGHER POWER LEVELS}

Second and third generation power systems to meet the energy demands of large lunar bases and colonies will eventually need to be designed with power outputs in the multimegawatt range $[1,2]$. Since for such power levels the heat rejection subsystem can represent over $50 \%$ of the total system mass, the use of lightweight $\mathrm{C}-\mathrm{C}$ radiators would have an even greater impact on total mass than for the $20 \mathrm{~kW}$ e power system considered here. Reactor shielding requirements would also be reduced by locating the reactor below ground level [4]. Figure 5 shows how this strategy might be applied to 
a second generation $\mathrm{CBC}$ power system, using flat $\mathrm{C}-\mathrm{C}$ radiators. To assure high overall power system reliability several parallel redundant power conversion units (PCUs) could be used with a single high temperature gas reactor heat source, as proposed for nuclear electric propulsion [14] systems. Figure 6 shows such a conceptual power plant using eight parallel redundant Brayton PCU's, each with its own radiator panel. The resulting "spoked wheel" radiator configuration is located on a reflective cover. Note that even though the panels have a partial view of each other, the view factor to the space sink is only reduced by about ten percent, thus requiring only a modest increase in deployed radiator area to compensate for this effect.

\section{CONCLUDING REMARKS}

Although national priorities and present funding limitations have resulted in a postponement of programs requiring permanent lunar bases, the results of this and other studies and the analysis tools used should facilitate future work in this area. It was shown that lightweight C-C heat pipes developed under the NASA LeRC "Advanced Radiator Concepts" project can significantly reduce lunar power system radiator and overall system mass. This mass reduction becomes even more drastic for high power level systems.

Reflective blankets covering the surface adjacent to vertically deployed radiators lower the effective sink lunar day temperature thereby reducing radiator area requirements.

Nuclear power systems with radiators designed for lunar day operation can be designed to produce excess power during the lunar night.

Availability of a huge terrestrial technology data base, coupled with the non-hazardous inert gas working fluids should permit component development for space power applications at lower cost than for other candidate systems requiring testing with liquid metals at high temperatures.

\section{ACKNOWLEDGMENTS}

This study was carried out at the NASA Lewis Research Center with support from the Rocketdyne Division of Rockwell International $\mathrm{Co}$.

\section{REFERENCES}

1. Angelo, J.A.; and Buden, D.; "Nuclear Energy for Lunar Base Applications", Paper IAF-85-180, 36th Congress of the International Astronautical Federation, Stockholm, Sweden, Oct. 7-12, 1985.
2. Trueblood, B.; Pressentin, R.; and Bruckner, A.P.: "Multimegawatt Nuclear Power Systems for Lunar Base Applications", Fourth Symposium on Space Nuclear Power Systems, Albuquerque, NM, Jan. 12-16, 1987.

3. Colozza, A.J. "Analysis of Lunar Regolith Thermal Energy Storage", NASA Contractor Report 189073, Nov. 1991.

4. Mason, L.S.; Bloomfield, H.S.; and Hainley, D.C. "SP100 Power System Conceptual Design for Lunar Base Applications", Sixth Symposium on Space Nuclear Power Systems, Albuquerque, NM, Jan. 8-12, 1989.

5. Zeilik, M. and Gaustad, J. "Astronomy - The Cosmic Perspective", 2nd Edition, John Wiley \& Sons, 1990.

6. Jefferies, K.S. et al., ed. "Solar Dynamic Power System Development for Space Station Freedom" NASA RP 1310, 1993.

7. Shepard, N.F. et al. "20 kW Space Reactor Power System using Brayton Cycle Conversion", 11th Symposium on Space Nuclear Power and Propulsion, Albuquerque, NM, Jan. 9-13, 1994.

8. Juhasz, A.J.: "An Overview of The Lewis Research Center Thermal Management Program", Conference on Advanced Space Exploration Initiative Technologies, cosponsored by AIAA, NASA, and OAI, Cleveland, OH, Sept. 4-6, 1991.

9. Rovang, R.D. et al. "Advanced Radiator Concepts for SP-100 Space Power Systems - Phase III Final Report, NASA CR-187170, Aug. 1990.

10. Rovang, R.D. et al. 1992, "Carbon-Carbon Heat Pipe Assembly", Proceedings of 10th Symposium of Space Nuclear Power and Propulsion", CONF-930103, American Institute of Physics, AIP Conf. No. 271, 1:539-543.

11. Rovang, R.D., Hunt, M.E., and Juhasz, A.J. "Testing of a Liquid Metal Carbon-Carbon Heat Pipe", 11th Symposium on Space Nuclear Power and Propulsion, Albuquerque, NM, Jan. 9-13, 1994.

12. Bammert, K.: "Remarks to the Problem of Optimum Design of Nuclear Gas Turbine Power Plants", Atomkernenergie, Jan./Feb. 1966.

13. Keller, C.; and Schmidt, D.: "Industrial Closed Cycle Gas turbines for Conventional and Nuclear Fuel," ASME Paper 67-GT-10, presented at the Gas Turbine Conference and Products Show, Houston, TX, 3/5-9, 1967.

14. Juhasz, A.J.; El-Genk, M.S.; and Harper, W.B.: "Closed Brayton Cycle Power System with a High Tem- . perature Pellet Bed Reactor Heat Source for NEP Applications", NASA TM-105933, presented at 10th Symposium on Space Nuclear Power and Propulsion, Albuquerque, NM, Jan. 10-14, 1993. 
Table 1: Carbon-Carbon Heat Pipe Mass Breakdown

\begin{tabular}{|c|c|c|}
\hline COMPONENT & T-300 Composite & P-95 WG Composite \\
\hline $\begin{array}{l}\text { DIMENSIONS } \\
\text { (SEE SKETCH) }\end{array}$ & $\begin{array}{l}L=91.4 \mathrm{~cm} ; D=2.5 \mathrm{~cm} \\
W=2.5 \mathrm{~cm} ; \quad I=0.1 \mathrm{~cm}\end{array}$ & $\begin{array}{l}L=91.4 \mathrm{~cm} ; D=2.5 \mathrm{~cm} \\
W=5 \mathrm{~cm} ; \quad T=0.1 \mathrm{~cm}\end{array}$ \\
\hline C-C SHELL & 169.5 & 214.0 \\
\hline LINER W, EVAPORATOR & 41.2 & 41.2 \\
\hline END CAPS & 13.1 & 13.1 \\
\hline FILL TUBES & 7.2 & 7.2 \\
\hline BRAZE & 22.5 & 22.5 \\
\hline WICK & 24.0 & 24.0 \\
\hline WORKING FLUID & 13.5 & 13.5 \\
\hline TOTAL MASS & 291.0 & 335.5 \\
\hline TWO SIDED RADIATING AREA - & $\cdot m^{2} \quad 0.1383$ & 0.2335 \\
\hline SPECIFIC MASS $\cdot \mathrm{kg}$ & $g / m^{2}$ & 1.45 \\
\hline
\end{tabular}

Table 2: Brayton Power System Component Mass Breakdown

\begin{tabular}{||l|c|c|}
\hline \multicolumn{1}{|c|}{ Component } & $\begin{array}{c}\text { Component Mass } \\
\mathrm{kg}\end{array}$ & $\begin{array}{c}\text { Component Mass } \\
\text { (Percent of Total) }\end{array}$ \\
\hline Reactor & 363 & 23.6 \\
Instrument Shield & 315 & 20.5 \\
$\begin{array}{l}\text { Source Heat Exchanger } \\
\text { \& Pump } \\
\text { Recuperator }\end{array}$ & 210 & 13.7 \\
$\begin{array}{l}\text { Turboalternator } \\
\text { Instrumentation } \\
\text { \& Controls }\end{array}$ & 100 & 6.6 \\
Main Radiator & 50 & 3.3 \\
Auxiliary Radiators & 80 & 5.2 \\
Radiator Heat Exchanger & 210 & 13.7 \\
\& Structure & 66 & 4.3 \\
\hline Total System Mass & 140 & 9.1 \\
\hline \hline
\end{tabular}


Table 3: Lunar 20 kWe CBC Minimum Power System Characteristics

\begin{tabular}{|c|c|c|c|c|}
\hline Gas Turbine Cycle Parameters & $\begin{array}{l}\text { Lunar Day } \\
\text { Traditional } \\
\text { Radiator } \\
1 \\
\end{array}$ & $\begin{array}{l}\text { Lunar Day } \\
\begin{array}{c}\text { C.C } \\
\text { Radiator } \\
2\end{array} \\
\end{array}$ & $\begin{array}{l}\text { Lunar Night } \\
\\
\text { C.C } \\
\text { Radiator } \\
3 \\
\end{array}$ & $\begin{array}{c}\text { Lunar Night } \\
\text { Reflective } \\
\text { Cover } \\
C-C \\
\text { Radiator } \\
4\end{array}$ \\
\hline Turbine Inlet Temperature - $K$ & 1350.00 & 1350.00 & 1350.00 & 1350.00 \\
\hline Cycle Temperature Ratio & 2.90 & 320 & 420 & 3.00 \\
\hline Compressor Inlet Temperature - $\mathrm{K}$ & 466.00 & 422.00 & 321.00 & 346.00 \\
\hline Compressor Pressure Ratio & 2.00 & 2.00 & 2.39 & 2.28 \\
\hline Compressor Exit Temperature - $\mathrm{K}$ & 643.00 & 586.00 & 483.00 & 509.00 \\
\hline Reactor HX Inlet Temperature - $\mathrm{K}$ & 1068.00 & 1062.00 & 1000.00 & 1017.00 \\
\hline Loop He/Xe Flowrate $-\mathrm{kg} / \mathrm{sec}$ & 1.04 & 0.86 & 0.53 & 0.59 \\
\hline Cycle Pressure Loss Parameter & 0.94 & 0.94 & 0.94 & 0.94 \\
\hline Recuperator Effectiveness & 0.95 & 0.95 & 0.95 & 0.95 \\
\hline Cycle Thermal Efficiency - \% & 27.10 & 32.24 & 43.30 & 40.60 \\
\hline Cycle Heat Rejected - kWt & 53.80 & 42.00 & 26.20 & 29.30 \\
\hline Radiator Duct Inlet Temperature - $K$ & 666.00 & 611.00 & 510.00 & 536.00 \\
\hline Radiator Duct Exit Temperature - $K$ & 466.00 & 422.00 & 321.00 & 346.00 \\
\hline Effective Radiator Temperature - $\mathrm{K}$ & 524.00 & 475.00 & 384.00 & 406.00 \\
\hline Space Sink Temperature - $K$ & 360.00 & 360.00 & 90.00 & 230.00 \\
\hline Main Radiator Area - $\mathrm{m}^{2}$ & 22.77 & 30.40 & 29.20 & 29.10 \\
\hline System Specific Power - W/kg & 13.71 & 14.81 & 15.24 & 15.20 \\
\hline System Specific Mass - kg/kW & 72.95 & 67.54 & 65.60 & 66.00 \\
\hline Total System Mass - kg & 1459.00 & $135: 00$ & 131200 & 1319.00 \\
\hline
\end{tabular}


Table 4: Lunar $20 \mathrm{kWe}$ CBC Selected Power System Characteristics and Performance

\begin{tabular}{|c|c|c|c|c|}
\hline $\begin{array}{l}\text { Gas Turbine Cycle Parameters } \\
\text { Column No. }\end{array}$ & $\begin{array}{l}\text { Lunar Day } \\
\text { Traditional } \\
\text { Radiator } \\
1\end{array}$ & $\begin{array}{l}\text { Lunar Day } \\
\text { C-C } \\
\text { Radiator } \\
2\end{array}$ & $\begin{array}{l}\text { Lunar Night } \\
\\
\text { C-C } \\
\text { Radiator } \\
3\end{array}$ & $\begin{array}{l}\text { Lunar Night } \\
\text { Reflective } \\
\text { Cover } \\
\text { C-C } \\
\text { Radiator } \\
4\end{array}$ \\
\hline Turbine Inlet Temperature - $\mathrm{K}$ & 1350.00 & 1350.00 & 1350.00 & 1350.00 \\
\hline Cycle Temperature Ratio & 3.40 & 3.40 & 8.40 & 3.40 \\
\hline Compressor Inlet Temperature - $\mathrm{K}$ & 397.00 & 397.00 & 397.00 & 397.00 \\
\hline Compressor Pressure Ratio & 2.00 & 2.20 & 2.00 & 2.00 \\
\hline Compressor Exit Temperature - $\mathrm{K}$ & 549.00 & 573.00 & 549.00 & 574.00 \\
\hline Reactor HX Inlet Temperature - $\mathrm{K}$ & 1064.00 & 1035.00 & 1064.00 & 1032.00 \\
\hline Loop He/Xe Flowrate $-\mathrm{kg} / \mathrm{sec}$ & 0.79 & 0.73 & 0.79 & 0.78 \\
\hline Cycle Pressure Loss Parameter & 0.94 & 0.94 & 0.94 & 0.94 \\
\hline Recuperator Effectiveness & 0.95 & 0.95 & 0.95 & 0.95 \\
\hline Cycle Thermal Efficiency - \% & 35.10 & 34.60 & 35.30 & 35.20 \\
\hline Cycle Heat Rejected - kWt & 37.00 & 37.80 & 36.70 & 36.80 \\
\hline Radiator Duct Inlet Temperature - $\mathrm{K}$ & 576.00 & 597.00 & 576.00 & 578.00 \\
\hline Radiator Duct Exit Temperature - $\mathrm{K}$ & 397.60 & 397.00 & 397.00 & 397.60 \\
\hline Effective Radiator Temperature - $\mathrm{K}$ & 442.00 & 448.00 & 455.00 & 455.00 \\
\hline Space Sink Temperature - $K$ & 360.00 & 360.00 & 90.00 & 230.00 \\
\hline Main Radiator Area - $\mathrm{m}^{2}$ & $4 !, 74$ & 39.60 & 21.00 & 22.60 \\
\hline System Specific Power - W/kg & 13.10 & 14.73 & 15.13 & 15.10 \\
\hline System Specific Mass - kg/kW & 76.64 & 67.90 & 66.10 & 66.20 \\
\hline Total System Mass - kg & 1533.00 & 1358.00 & 1322.00 & 1325.00 \\
\hline
\end{tabular}




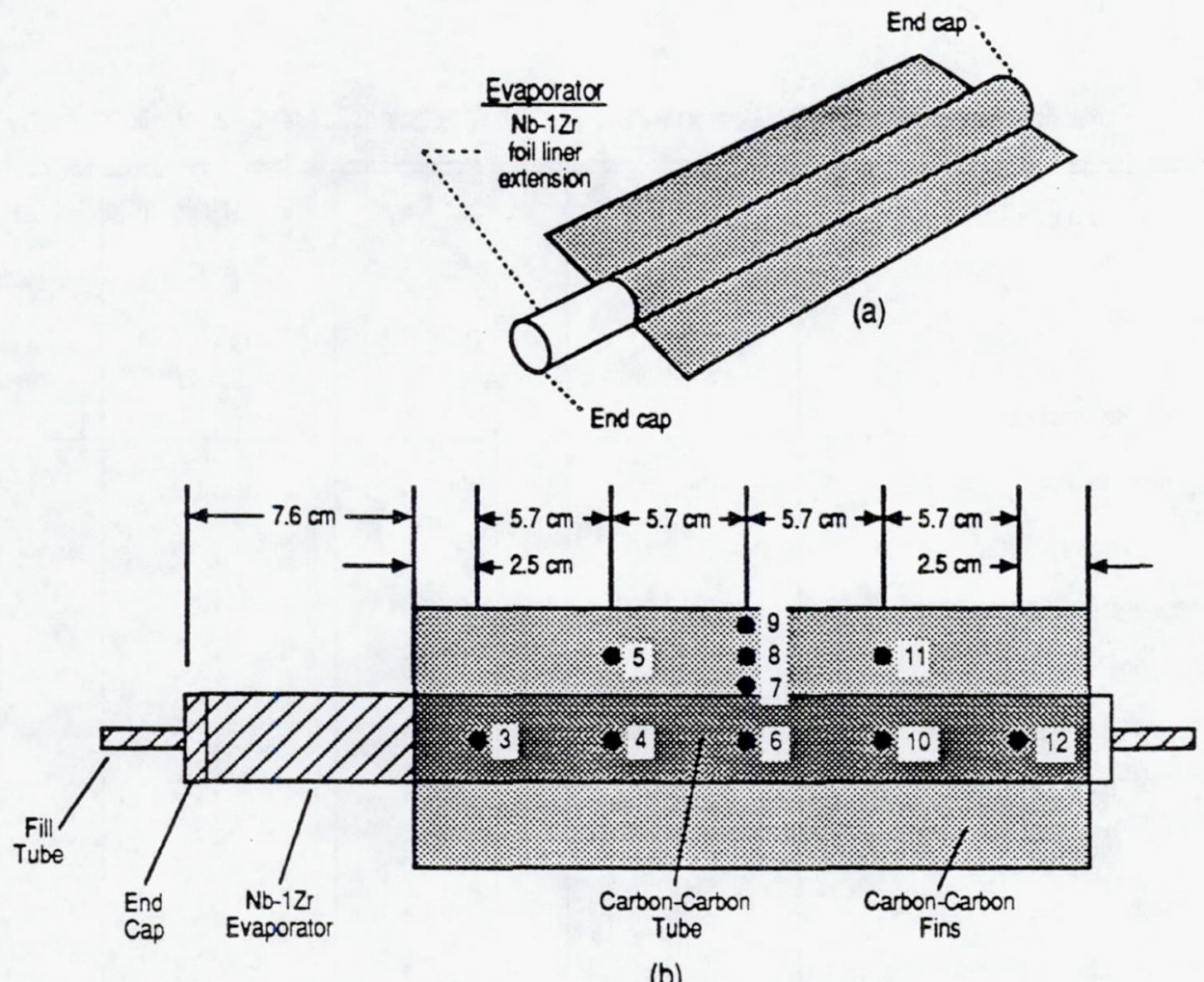

(b)

Figure 1: Carbon-Carbon Heat Pipe Radiator Element

(a) Sketch showing $\mathrm{C}-\mathrm{C}$ shell and Metallic Liner/Evaporator Extension

(b) Test Article (top view) showing Thermocouple Locations

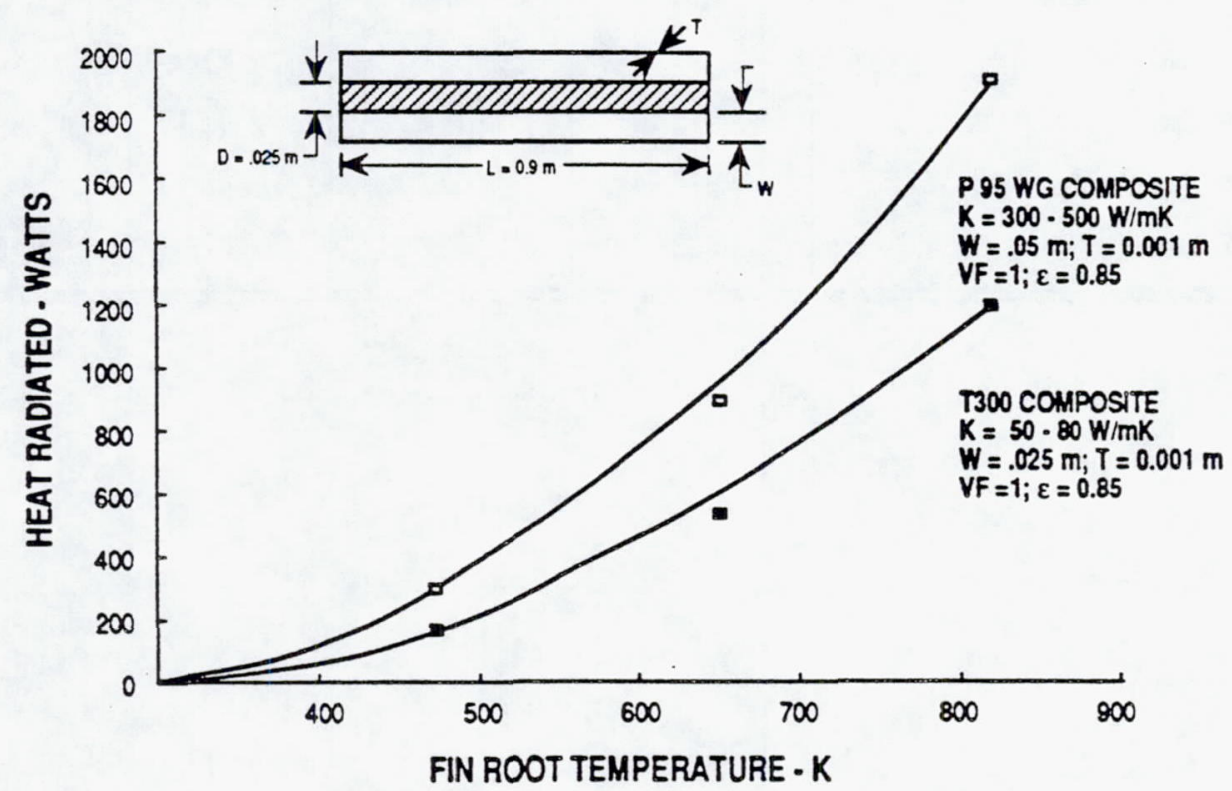

Figure 2: Thermal Conductivity Effect on Finned Heat Pipe Performance 

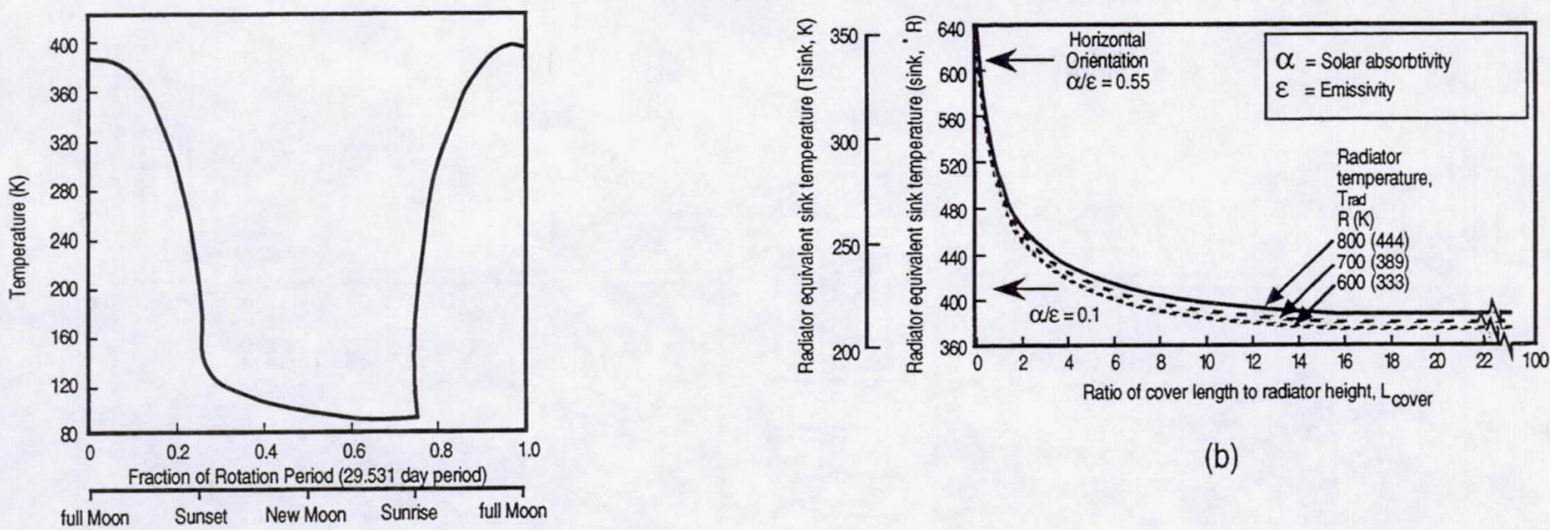

(b)

(a)

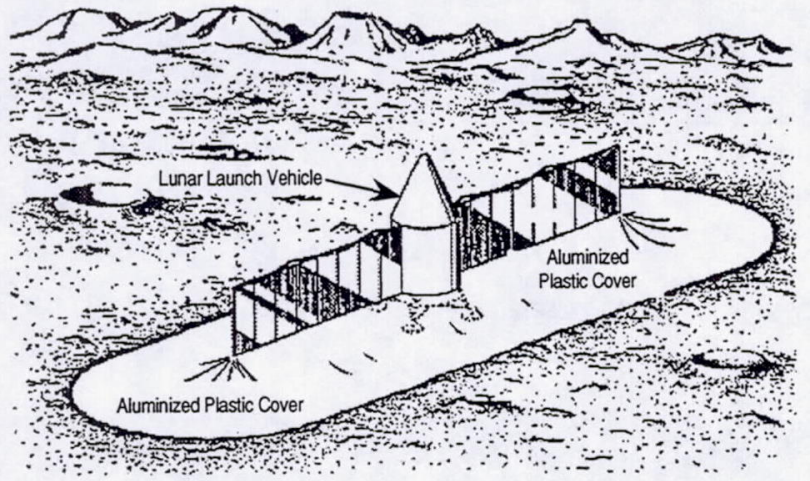

(c)

Figure 3: Lunar Environment during Synodic Month

a) Lunar Surface Temperature Variation

b) Effect of Reflective Cover on Sink Temperature

c) Lunar Outpost (Conceptual Sketch)

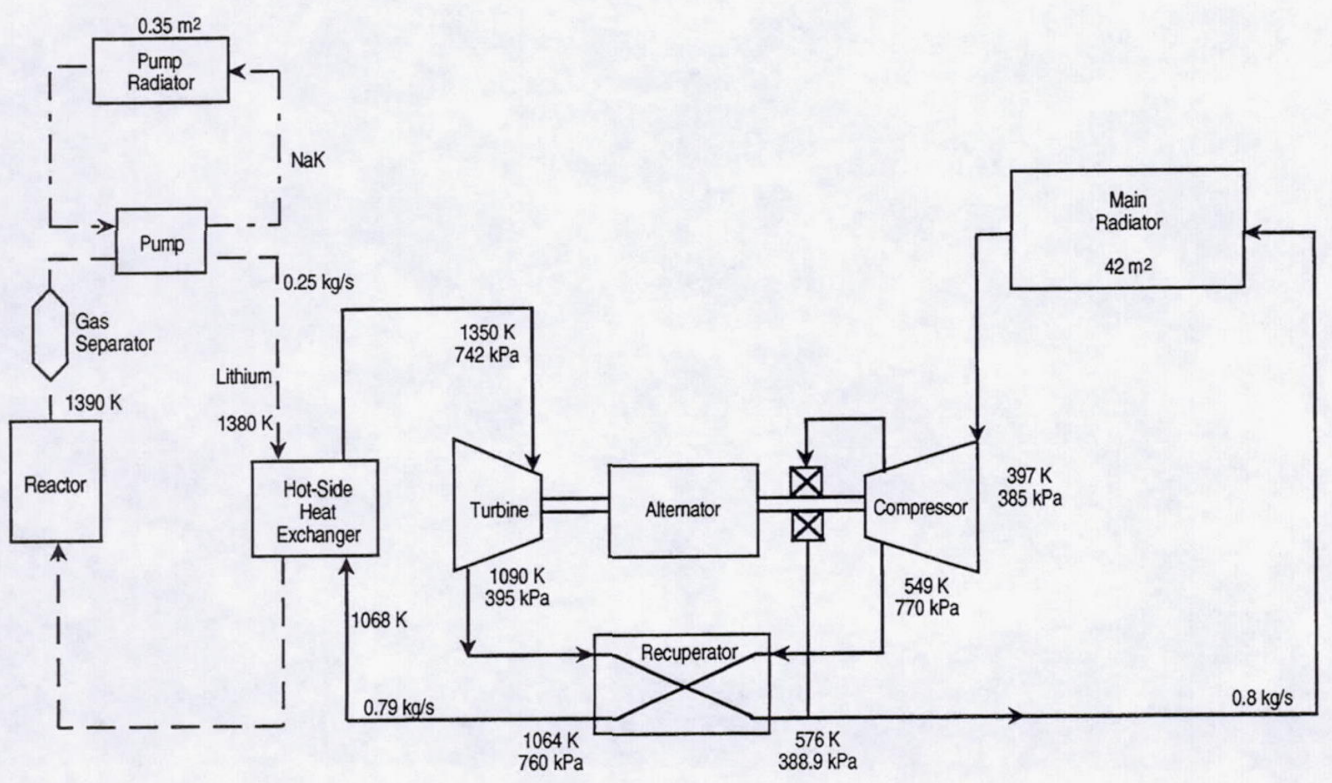

Figure 4: Base Line Schematic for Lunar Power System 




Figure 5: Cutaway View of Second Generation Nuclear Power System for Lunar Base



Figure 6: Artist's rendering of Integrated Nuclear Power System for Megawatt Level Lunar Powerplant 
Public reporting burden for this collection of information is estimated to average 1 hour per response, including the time for reviewing instructions, searching existing data sources, gathering and maintaining the data needed, and completing and reviewing the collection of information. Send comments regarding this burden estimate or any other aspect of this collection of information, including suggestions for reducing this burden, to Washington Headquarters Services, Directorate for Information Operations and Reports, 1215 Jefferson Davis Highway, Suite 1204, Arlington, VA 22202-4302, and to the Office of Management and Budget, Paperwork Reduction Project (0704-0188), Washington, DC 20503.

\begin{tabular}{|l|l|l}
\hline 1. AGENCY USE ONLY (Leave blank) & $\begin{array}{c}\text { 2. REPORT DATE } \\
\text { May } 1994\end{array}$ & $\begin{array}{r}\text { 3. REPORT TYPE AND DATES COVERED } \\
\text { Technical Memorandum }\end{array}$
\end{tabular}

4. TITLE AND SUBTITLE

Development of Lightweight Radiators for Lunar Based Power Systems

6. AUTHOR(S)

Albert J. Juhasz and Harvey S. Bloomfield
5. FUNDING NUMBERS

WU-233-02-0B

8. PERFORMING ORGANIZATION REPORT NUMBER

E-8880

Lewis Research Center

Cleveland, Ohio 44135-3191
10. SPONSORING/MONITORING AGENCY REPORT NUMBER

NASA TM-106604

Washington, D.C. 20546-0001

11. SUPPLEMENTARY NOTES

Prepared for the 5th European Symposium on Space and Environmental Control Systems and the 24th International Conference on Environmental Systems, cosponsored by ESA, SAE, ASME, AIChE, and AIAA, Friedrichshafen, Federal Republic of Germany, June 20-23, 1994. Albert J. Juhasz and Harvey S. Bloomfield, NASA Lewis Research Center. Responsible person, Albert J. Juhasz, organization code $5440,(216) 433-6134$.

12a. DISTRIBUTION/AVAILABILITY STATEMENT

Unclassified - Unlimited

Subject Categories 91 and 37

\section{ABSTRACT (Maximum 200 words)}

This report discusses application of a new lightweight carbon-carbon (C-C) space radiator technology developed under the NASA Civil-Space Technology Initiative (CSTI) High Capacity Power Program to a $20 \mathrm{kWe}$ lunar based power system. This system comprises a nuclear (SP-100 derivative) heat source, a Closed Brayton Cycle (CBC) power conversion unit with heat rejection by means of a plane radiator. The new radiator concept is based on a $\mathrm{C}$ - $\mathrm{C}$ composite heat pipe with integrally woven fins and a thin walled metallic liner for containment of the working fluid. Using measured areal specific mass values $(1.5 \mathrm{~kg} / \mathrm{m} 2)$ for flat plate radiators, comparative CBC power system mass and performance calculations show significant advantages if conventional heat pipes for space radiators are replaced by the new C-C heat pipe technology.

\section{SUBJECT TERMS}

Carbon-Carbon radiators; Space heat rejection; Lunar power system

15. NUMBER OF PAGES

12

16. PRICE CODE

$\mathrm{A} 03$

\begin{tabular}{c|c|c|}
\hline $\begin{array}{c}\text { 17. SECURITY CLASSIFICATION } \\
\text { OF REPORT } \\
\text { Unclassified }\end{array}$ & $\begin{array}{c}\text { 18. SECURITY CLASSIFICATION } \\
\text { OF THIS PAGE } \\
\text { Unclassified }\end{array}$ & $\begin{array}{c}\text { 19. SECURITY CLASSIFICATION } \\
\text { OF ABSTRACT } \\
\text { Unclassified }\end{array}$ \\
\hline
\end{tabular}

